\title{
ZEITSCHRIFT FÜR SOZIALREFORM
}

JOURNAL OF SOCIAL POLICY RESEARCH

EDITOR-IN-CHIEF

Werner Eichhorst

EDITORS

Thomas Gerlinger

Gerhard Igl

Sigrid Leitner

Frank Nullmeier

Christine Trampusch

Traute Meyer

Katja Möhring

Melike Wulfgram

EDITORIAL BOARD

Ulrike Davy

Ulrike Famira-Mühlberger

Miriam Hartlapp

Katja Hujo

Clémence Ledoux

Janine Leschke

Jacqueline O'Reilly

Georg Picot

Monika Queisser

Winfried Sü $\beta$

Cornelius Torp

Annette Zimmer

DE GRUYTER

OLDENBOURG 
ABSTRACTED/INDEXED IN Baidu Scholar · CNKI Scholar (China National Knowledge Infrastructure) - CNPIEC: cnpLINKer - Dimensions - EBSCO (relevant databases) - EBSCO Discovery Service - Google Scholar · IBR (International Bibliography of Reviews of Scholarly Literature in the Humanities and Social Sciences) · IBZ (International Bibliography of Periodical Literature in the Humanities and Social Sciences) $\cdot$ J-Gate $\cdot$ JournalTOCs $\cdot$ KESLI-NDSL (Korean National Discovery for Science Leaders) · Microsoft Academic $\cdot$ MyScienceWork $\cdot$ Naviga (Softweco) $\cdot$ Primo Central (ExLibris) · Publons · QOAM (Quality Open Access Market) · ReadCube · Semantic Scholar · Summon (ProQuest) · TDNet · Ulrich's Periodicals Directory/ulrichsweb · WanFang Data · WorldCat (OCLC)

ISSN 0514-2776 · e-ISSN 2366-0295

Alle Informationen zur Zeitschrift, wie Hinweise für Autoren, Open Access, Bezugsbedingungen und Bestellformulare, sind online zu finden unter www.degruyter.com/journals/zsr

VERANTWORTLICHER HERAUSGEBER Prof. Dr. Werner Eichhorst, IZA - Institute of Labor Economics, Schaumburg-Lippe-Str. 5-9, 53113 Bonn, Tel: +49 228 3894-531, E-Mail: eichhorst@iza.org

REDAKTION Dennis Redeker, Universität Bremen, SOCIUM - Forschungszentrum Ungleichheit und Sozialpolitik, Mary-Somerville-Straße 5, 28359 Bremen, Tel: +49 421 218-66454,

E-Mail: zsr@uni-bremen.de

VERLAG Walter de Gruyter GmbH, Berlin/Boston, Genthiner Straße 13, 10785 Berlin, Germany

JOURNAL MANAGER Jana Kuchta, De Gruyter, Genthiner Straße 13, 10785 Berlin, Germany, Tel.: +49 (0)30 260 05-228, Fax: +49 (0)30260 05-250, E-Mail: jana.kuchta@ degruyter.com

ANZEIGENVERANTWORTLICHE Jana Kuchta, De Gruyter, Genthiner Straße 13, 10785 Berlin, Germany, Tel.: +49 (0)30 260 05-170, E-Mail: anzeigen@ degruyter.com

(C) 2021 Walter de Gruyter GmbH, Berlin/Boston

DRUCK Franz X. Stückle Druck und Verlag e.K., Ettenheim

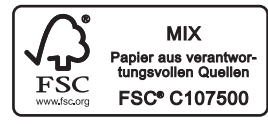




\section{Table of Contents}

Special Issue:

Governing the Poor - Migration and Poverty

Lisa Marie Borrelli and Yann Bochsler

Editorial: Governing the Poor - Migration and Poverty - 363

Béatrice Bertho and Hélène Martin

“An Especially Thankless Work"? Filtering Practices in Emergency Shelters and Ethical Dilemmas for Street-level Social Workers in Western

Switzerland - 387

\section{Annika Lindberg}

The Production of Precarity in Denmark's Asylum Regime - 413

Lucia M. Lanfranconi, Yu-Ling Chang and Ayda Basaran

At the intersection of immigration and welfare governance in the United States:

State, county and frontline levels and clients' perspectives - 441

Yann Bochsler

Governing Young Poor in Switzerland and Reinforcing Their Work Ethics - 471

Elizabeth Fox

Child Money and Food Stamps: A comparative analysis of Mongolian welfare programmes in the Ger Districts of Ulaanbaatar — 499

Roland Atzmüller, Alban Knecht and Michael Bodenstein

Punishing the Poor and Fighting "Immigration into the Social System" Welfare Reforms by the Conservative and Far-right Government in Austria 2017-2019 -525 